\title{
Implementasi Teknologi Informasi di Bidang Kesehatan
}

\author{
Antonio Alfarez Hidayat ${ }^{1}$ \\ 1 Faculty Of Computer Universitas Mitra Indonesia \\ antonio.student@umitra.ac.id
}

\section{PENDAHULUAN}

Pendekatan Keilmuan Computer Science menjadi rujukan dalam implementasi Produk Teknologi. Penerapan Sistem Informasi menjadi hal yang sangat fundamental (Febriani \& Putra, 2013) . Penggunaan penerapan teknologi dimasa sekarang dan masa mendatang menjadi hal yang sangat penting dalam perkembangan intelegensia Technolo gy (Putra \& Febriani, 2017). Produksi aplikasi berbasis Humanity membuat aplikasi berkembang dengan sangat cepat, sisi efektifitas dan sisi efisiensi menjadi hal yang sangat berperan dalam perkembangan teknologi tersebut (Putra et al., 2018). Sehingga factor dalam pencarian keterbaruan ataupun novelty menjadi hal yang harus dikembangkan diberbagai lini (Putra et al., n.d.).

\section{PERTANYAAN-001}

Berisi deskripsi tentang pertanyaan yang dilontarkan oleh Bpk. Dr. ( c ) Arie Setya Putra, CA, S.Kom, M.T.I ; Menurut anda apakah Infrastruktur Teknologi Informasi menjadi kebutuhan Penting dalam Perusahaan Khususnya Bidang Kesehatan, Berikan Contoh Detailnya? 


\section{HASIL JAWABAN}

Jabarkan Jawaban Anda :

\section{JAWABAN-001}

1. Teknologi Informasi telah banyak digunakan untuk mendukung proses bisnis yang terjadi pada perusahaan, baik bidang ekonomi maupun kesehatan. Dengan hadirnya aplikasi-aplikasi dan layanan e-bussiness, e-commerce, e-banking dan lain-lain. Kebutuhan efisiensi waktu dan biaya menyebabkan setiap pelaku bisnis merasa perlu menerapkan teknologi informasi dalam lingkungan kerja.

Semakin berjalannya waktu perkembangan teknologi semakin maju dengan pesat. Tidak dapat dipungkiri bahwa teknologi sangat membantu kita dalam kehidupan sehari-hari. Sebut saja kemajuan teknologi dalam moda transportasi, kini kita sudah tidak perlu lagi berjalan jauh untuk pergi ke suatu tempat. Karena saat ini sudah ada berbagai macam moda transportasi yang dapat membawa kita ke tujuan. Selain itu kini kita juga telah mengenal yang namanya ponsel atau telepon genggam. Hanya dengan ponsel kini kita sudah bisa menjelajahi dunia. Berbagai macam informasi dari berbagai belahan dunia dapat kita akses hanya dengan menggunakan telepon genggam. Selain permasalahan jarak dan komunikasi, kini teknologi juga merambah ke berbagai sektor termasuk sektor kesehatan. Banyak sekali manfaat dan kemudahan yang dihasilkan oleh teknologi dalam bidang kesehatan.

\section{Manfaat Teknologi di Bidang Kesehatan}

\section{Memudahkan Pasien}

Contohnya : Memudahkan pasien. Hadirnya teknologi sangat memudahkan pasien terutama dalam mengakses informasi dan pelayanan kesehatan. Hanya dengan ponsel atau komputer, kini pasien dapat mengakses berbagai macam informasi kesehatan di internet.

Selain itu, berbagai macam layanan kesehatan yang hadir secara online juga memudahkan pasien dalam mengakses pelayanan kesehatan. Pasien kini dapat mengakses informasi, mendapat layanan konsultasi, hingga melakukan penebusan resep obat secara online. 


\section{Mempersingkat Waktu Tunggu Pasien}

Contohnya : Selain memudahkan pasien dalam mengakses pelayanan kesehatan, teknologi di bidang kesehatan juga dapat mempersingkat waktu tunggu pasien. Biasanya jika Anda melakukan pelayanan kesehatan di rumah sakit, Anda dapat mengantri hingga berjam-jam untuk mendapat pelayanan. Namun kini dengan adanya teknologi, Anda tidak perlu menunggu lama. Anda dapat membuat janji secara online lalu melakukan konsultasi secara tatap muka di pelayanan kesehatan. Anda juga bisa membuat janji untuk melakukan konsultasi secara online dengan dokter.

\section{Mempermudah Dokter dan Tenaga Medis Lainnya dalam Menolong Pasien}

Contohnya : Dengan adanya perkembangan teknologi di bidang kesehatan, dokter dan tenaga medis lainnya jadi lebih mudah dalam menjangkau pasien. Kini hanya dengan koneksi internet dan ponsel, dokter dan tenaga medis lainnya dapat menolong pasien tanpa harus bertatap muka. Dokter juga dapat memiliki waktu dan tempat yang lebih fleksibel untuk menolong pasien.

\section{Meningkatkan Derajat Kesehatan Masyarakat}

Contohnya : Dengan akses yang lebih cepat dan mudah dijangkau, kesehatan masyarakat tentunya akan meningkat. Terutama berbagai informasi yang tersedia di internet, ditambah layanan kesehatan secara online dapat meningkatkan pengetahuan pasien dan membuat pasien lebih cepat untuk ditangani.

Selain itu, dengan berkembangnya teknologi alat-alat kesehatan juga mengalami kemajuan. Berbagai macam alat kesehatan yang mempermudah dokter dalam mendiagnosa dan menangani pasien. Beberapa teknologi yang mempermudah dokter dalam menangani pasien adalah alat cuci darah. Tentunya hal ini sangat membantu dalam meningkatkan derajat kesehatan masyarakat.

\section{Penyimpanan dan Perawatan Data Menjadi Lebih Mudah}

Contohnya : Penyimpanan dan perawatan data menjadi lebih mudah. Teknologi tidak hanya memudahkan dari sisi pasien dan tenaga medis saja. Namun ternyata juga membantu sisi penyedia layanan kesehatan. Dengan adanya teknologi, penyedia layanan menjadi lebih mudah dalam menyimpan data-data penting milik pasien seperti rekam medis, atau data penting lainnya. 
Penyedia layanan kesehatan dapat membuka dan menyimpan data kembali secara mudah.

\section{Membuat Alur Kerja Menjadi Lebih Sederhana}

Contohnya : Karena dengan adanya pelayanan secara online, alur yang disiapkan tidak sepanjang ketika pasien melakukan pelayanan di rumah sakit secara tatap muka. Pasien dapat membuat janji secara online dan melakukan konsultasi dengan waktu yang telah ditentukan. Sedangkan jika dilakukan secara tradisional, pasien perlu mendaftar ke pelayanan kesehatan, lalu mengambil nomor antrian. Setelah itu pasien perlu mengantri lama untuk dapat berkonsultasi dengan dokter. Hal ini tentu memakan tenaga dan waktu yang cukup besar. Sehingga teknologi di bidang kesehatan menjadi solusi dari permasalahan ini.

\section{Alat Pemasaran}

Contohnya : Pelayanan kesehatan dapat menjadikan teknologi sebagai alat pemasaran layanan kesehatannya. Pelayanan kesehatan dapat memasang iklan atau membuat website yang memuat informasi mengenai produk-produknya. Hal ini akan membantu penyedia jasa layanan kesehatan menjangkau pasien dengan lebih luas. Terlebih dengan adanya teknologi orang-orang dapat mengakses berbagai macam informasi meski dengan jarak yang jauh.

\section{Monitoring Secara Online}

Contohnya : Dengan adanya perkembangan teknologi, hal ini memungkinkan dokter untuk melakukan monitoring kondisi pasien secara online. Pasien dengan kondisi yang hampir pulih dapat tetap dimonitoring secara online oleh dokter atau tenaga medis lainnya.

\section{Menjangkau Pasien Lebih Luas}

Contohnya : Dengan adanya teknologi, pasien dari berbagai daerah dapat mengetahui mengenai keberadaan dan informasi pelayanan kesehatan secara mudah. Hal ini akan meningkatkan angka kunjungan pasien ke pelayanan kesehatan dan membuat pelayanan kesehatan lebih dikenal oleh masyarakat. 


\section{Mencegah Penularan Penyakit}

Dengan adanya teknologi pasien dapat mencegah penularan penyakit. Rumah sakit merupakan tempat di rawat dan dilakukannya berbagai tindakan bagi orang-orang yang sedang sakit.

Kemungkinan kuman penyebab penyakit yang bertebaran di area rumah sakit sangat memungkinkan pasien sehat tertular penyakit.

Contohnya : Seperti saat ini. Kini kita sedang dilanda pandemi COVID-19. Penularannya yang sangat cepat tentunya membuat kita khawatir untuk bepergian ke luar rumah termasuk rumah sakit. Oleh karena itu, dengan adanya teknologi di bidang kesehatan sangat membantu dalam mencegah penularan penyakit.

\section{DAFTAR REFERENSI}

Febriani, 0., \& Putra, A. (2013). Sistem Informasi Monitoring Inventori Barang Pada Balai Riset Standardisasi Industri Bandar Lampung. Jurnal Informatika Darmajaya, 13(1), 90-98.

Putra, A. S., \& Febriani, O. M. (2017). Knowledge Management Online Application in PDAM Lampung Province. International Conference on Information Technology and Business (ICITB), 1, 181-187.

Putra, A. S., Febriani, O. M., \& Bachry, B. (2018). Implementasi Genetic Fuzzy System Untuk Mengidentifikasi Hasil Curian Kendaraan Bermotor Di Polda Lampung. SIMADA (Jurnal Sistem Informasi Dan Manajemen Basis Data), 1(1), 21-30.

Putra, A. S., Sukri, H., \& Zuhri, K. (n.d.). Sistem Monitoring Realtime Jaringan Irigasi Desa (JIDES) Dengan Konsep Jaringan Sensor Nirkabel. IJEIS (Indonesian Journal of Electronics and Instrumentation Systems), 8(2), 221-232. 